OPEN ACCESS

Citation: J. Cancela (2020) Some politics is local: the determinants of engagement in local and national politics across Europe. Quaderni dell'Osservatorio elettorale - Italian Journal of Electoral Studies 83(1): 29-44. doi: 10.36253/qoe-9530

Received: May 04, 2020

Accepted: June 10, 2020

Published: July 28, 2020

Copyright: (c) $2020 \mathrm{~J}$. Cancela. This is an open access, peer-reviewed article published by Firenze University Press (http://www.fupress.com/qoe) and distributed under the terms of the Creative Commons Attribution License, which permits unrestricted use, distribution, and reproduction in any medium, provided the original author and source are credited.

Data Availability Statement: All relevant data are within the paper and its Supporting Information files.

Competing Interests: The Author(s) declare(s) no conflict of interest.

\section{Some politics is local: the determinants of engagement in local and national politics across Europe}

\author{
Jỗo CANCELA \\ Department of Political Studies, Universidade NOVA de Lisboa, Portugal \\ E-mail: joaocancela@fcsh.unl.pt
}

\begin{abstract}
Understanding the roots of political engagement has been one of the critical tasks performed by students of comparative political behaviour. This paper adds to the literature by examining the determinants of political discussion about local and national affairs in Europe. A series of multilevel logit models are fitted to the data ( $n=28,563$ from 31 European countries) to test the individual and country level determinants of political discussion about local and national matters. At the individual level, we find that gender, the type of community, the type of civil society organisations people are members of, and their level of education affect the type of politics they engage with. At the macro level, citizens from countries with a higher economic development are more likely to engage in discussions about national affairs, while the impact of local government autonomy does not seem to make individuals more likely to engage in discussions about local politics. The findings suggest that if local politics is considered the share of politically disengaged citizens can be smaller than is typically estimated. The full range of democratic practice may thus remain underappreciated if non-national politics is left out of the picture in the study of political engagement.
\end{abstract}

Keywords. Political engagement, political discussion, local politics, geographical scale, Europe.

\title{
INTRODUCTION
}

The intensity and scope of citizen engagement in established democracies has been one of the major topics of concern in the field of comparative political behaviour in recent decades (Lijphart 1997; van Deth 2014). According to various authors, citizens have grown increasingly disaffected from their political systems and are less prone to engage with politics than they once were. This growth in political detachment has been considered one of the main symptoms of the malaise that has affected several democratic polities in recent years (Mair 2013, 43). Other authors counterargue that there are currently more ways of participating in politics than in earlier decades (Dalton 2014). Per this account, the case is not so much that citizens are becoming detached from politics; instead, they have found different, previously unavailable ways of expressing their stances that go beyond the tradi- 
tional realm of conventional participation. In any case, there is a considerable theoretical and practical interest in understanding what can lead to a larger portion of citizens becoming more engaged with their political systems.

Given the centrality of this topic in the literature, it is somewhat puzzling that a much less explored avenue of research has been the role played by the "geographical scale" (Agnew 2002, 17) towards which such political involvement is targeted ${ }^{1}$. The existence of overlapping layers of government - local, national and, in some cases, regional and supra-national - is by now an archetypal attribute of democratic polities (L. Hooghe and Marks 2001). But only recently have researchers given systematic consideration to differences in degrees of involvement towards each of them. It has been shown, for instance, that the gender gap in self-reported interest in politics depends on the territorial level in question (Coffé 2013) and that the levels of factual knowledge about politics also vary depending on the scale at stake (Rapeli 2014; Shaker 2012). These and other contributions, which are reviewed in greater detail in the following section, suggest that long held assumptions about the determinants of political engagement should be refined.

Against that backdrop, this article examines the determinants of frequency of discussion about national and local political matters in a wide set of European countries. Instead of assuming beforehand that the determinants of political discussion are one-dimensional - i.e. that they do not vary depending on the territorial level of government at stake - we test whether that is actually the case. The analysis is pursued by examining the roots of different profiles of engagement in local and national politics, therefore allowing us to grasp the origins of qualitatively different patterns of political involvement.

The article introduces three novel aspects with respect to the previous literature about political engagement towards different geographical scales. First, rather than examining subjective interest or objective knowledge, it takes a new dependent variable into focus: the frequency of political discussion. Political discussion is often used as a proxy for political engagement, yet it has remained overlooked why some individuals discuss some dimensions of politics more frequently than others. Second, the empirical analysis is not restricted to a single country, rather extending onto 31 European countries, thus offering room for generalizing with greater confi-

\footnotetext{
1 Throughout this article, the notions of "territorial level" and "geographical scale" will be used interchangeably to refer to the various realms of politics with which ordinary citizens can interact, but particularly the local and the national.
}

dence. The countries under analysis include the member-states of the EU and candidate countries at different stages of their economic and political development, therefore providing an ample range of national contexts. Third, the article tests a broader range of hypotheses in comparison with previous research, both at the individual and macro-level. By testing the impact of economic development and decentralisation we specifically account for the multilevel structure of the data and are able to understand that variations are due mostly to individual rather than country-level factors - contrarily to what research about "generalist" political engagement would make us expect (Inglehart 1990; Sanders and Bellucci 2012).

The results show that more than a quarter of individuals report discussing local and national political issues with distinct frequencies. Interestingly, this is not at the expense of local politics, which is more relevant for a significant share (15\%) of respondents. Besides, the same factors can play different roles in fostering (or preventing) discussion depending on the level at stake. These results have relevant implications given the status of long-held debates about the volume of political engagement in democratic political systems. A classical thesis about political change in developed countries asserts that a process of "nationalization of politics" dilutes the relevance of local contexts and peculiarities and, therefore, their role as fosterers of political engagement (Caramani 2004; Sellers et al. 2013, 1-10). However, our analysis shows that the profile of an engaged citizen is not as rigidly defined as could be assumed if we focused exclusively on the national level of politics. One way to interpret our findings is that local politics might provide a gateway to attract to the fore of politics writ large citizens that are otherwise disengaged.

The remainder of the article is structured as follows. The next section reviews the most relevant literature and presents the research hypotheses, and the third section introduces the data and models. The fourth section reports the results of the analysis. The article concludes with a discussion about the findings and what they might imply for our understanding of political engagement in a comparative perspective.

\section{Literature and hypotheses}

Two converging analytical routes downplay, either implicitly or explicitly, the significance of territorial levels in explaining the patterns and sources of political engagement. The first approach consists in focusing on engagement writ large, regardless of the geographical 
scale at stake (Baybeck 2014, 98). For instance, authors dealing with political involvement frequently take into account actions conducted at various territorial levels, but then pool them together into a single composite dimension (Verba, Schlozman, and Brady 1995). Also, the wording of questions upon which most of survey research about interest in politics is based typically does not refer to a specific territorial level, therefore denoting what we may label as a generalist engagement with politics (van Deth and Elff 2004; Sanders and Bellucci 2012). The consequence is that scholars end up dealing with the determinants of involvement with politics in a broad sense, without probing whether their conclusions can be extended to different geographical scales.

A second approach that leads to neglecting the importance of territorial levels is dealing exclusively with one of them, which more often than not is the national. In such cases, the instruments used to measure political involvement do not account for other scales, making it impossible to trace whether individuals invest similar amounts of their time and attention span in following different realms of politics. While it is hard to dispute that it is indeed the national level of politics that has the strongest impact on the lives of a majority of citizens, focusing only on it may conceal relevant dimensions of how citizens interact with the political environments that surround them (Oliver 2012, 1-2).

As stated in the introduction, this article takes the (self-reported) frequency of political discussion as a proxy for political engagement. In examining this variable we follow previous studies which have used it to measure "political involvement" (Inglehart 1990, 342), "political interest" (van Deth and Elff 2004, 480) or "informal political engagement" (Sanders and Bellucci 2012). This variety of conceptual labels should not distract us from the straightforward assumption shared by all these studies: individuals who state that they discuss politics frequently are expected to be more involved and interested in politics than those who report never doing so. Indeed, frequency of political discussion has been found to be highly correlated with variables such as subjective interest in politics, political sophistication and exposure to news coverage of current affairs (Kittilson and Schwindt-Bayer 2010, 995).

Though not as dominant a topic in the political behaviour literature as voter turnout and other modes of political participation, the volume of research aimed at unveiling the roots of political discussion has increased in recent years ${ }^{2}$. It is now accepted that both individual

\footnotetext{
${ }^{2} \mathrm{~A}$ branch of the literature that falls behind the scope of this article deals with the extent to which political discussions are circumscribed to like-minded individuals (Eveland and Hively 2009).
}

and macro-level factors play a role in fostering it (Inglehart 1990). The literature presents some lines of overall convergence, but there is still disagreement regarding the magnitude and directionality of some effects. Moreover, since we attempt to disentangle the roots of political discussion about local affairs, on the one hand, and national issues, on the other, in building our research hypotheses we will also look for relevant cues from studies of closely related dependent variables.

When it comes to explaining individual-level differences in the frequency of political discussion, gender is among the factors that has attracted the most attention (Kittilson and Schwindt-Bayer 2010). Cross-national studies have shown the persistence of a gender gap in the frequency of (generalist) political discussion, although its magnitude has been reported to be in decline for a while now (Inglehart 1990, 348). Based on an analysis of data from a British sample, Coffé (2013) shows that male respondents tend to report higher levels of subjective interest in national and international issues, whereas female respondents are relatively more interested in local affairs. Thus, identifying politics exclusively with the national sphere may induce an overestimation of the political apathy of women, and exaggerate the perceived gender gap in political engagement. In line with the findings presented by Coffé (2013) we expect that:

H1- Women will tend to have a higher tendency to engage in discussions about local politics, while men will tend be more engaged in discussions about national politics.

Another strand of literature suggests that the type of community where individuals live in may influence the type of political discussion they engage with. In a classical study of local politics in France, Tarrow (1971, 356) highlights that some citizens from rural communities would report an ostensive detachment towards national politics and parties, while remaining actively engaged with local political affairs. Moreover, we know that inhabitants from cities (Rapeli 2014) display higher levels of factual political knowledge regarding national affairs, whereas individuals from rural areas tend to perform better when asked about local matters. It has also been documented that while overall levels of voter turnout tends to be somewhat higher in less populated areas, this is especially the case when it comes to local elections (Cancela and Geys 2016). Based on these various findings we thus hypothesise that:

H2 - Individuals from rural areas will be more engaged in discussions about local politics, while city residents will be more engaged in discussions about national politics. 
Our third hypothesis regards the impact of education and socioeconomic status. In their analysis of responses from a representative US sample surveyed in 1989, Verba et al. (1995) find that political discussion is positively affected by the level of income but that educational resources do not seem to have an impact. An analysis of survey data from Hong Kong leads to similar conclusions (Lee 2009). Conversely, based on longitudinal data, Inglehart finds that those who achieve higher levels of education are consistently more likely to discuss politics (Inglehart 1990, 345). This finding was supported by subsequent analyses (Sanders and Bellucci 2012; van Deth and Elff 2004). Inglehart $(1990,351)$ also unveils evidence of life-cycle effects, as there is a curvilinear (inverted-U) distribution of political discussion after controlling for the fact that younger generations hold higher levels of education. A survey about the levels of factual levels of political knowledge in Philadelphia reveals that the performance gap between lowly and highly educated people is diminished once local politics is taken into account (Shaker 2012).

We hypothesise that this relationship can also be found in political discussions, as the local level of politics may present itself as having immediate relevance to the lives of less educated individuals, while presenting comparatively lower hurdles for discussing it. Conversely, those in the higher end of the social pyramid are expected to consume more information about national political issues (Verba, Schlozman, and Brady 1995) and translate such exposure into more frequent discussions about it. Therefore, we expect that:

H3 - Respondents with higher levels of education and socioeconomic status will be more engaged in discussions about national politics, while respondents with lower levels of education and socioeconomic status will be more engaged in discussions about local politics

Our following hypotheses deal with the impact of civil society organisations in fostering political engagement. A considerable number of empirical studies have shown that members of associations consistently exhibit higher levels of political participation than non-members (Almond and Verba 1965; Verba, Schlozman, and Brady 1995; Putnam 2000). While some contend that organisations do not generate more engaged individuals but instead pool them together (van der Meer and van Ingen 2009), we can nevertheless expect that members of organisations will discuss politics more frequently than non-members. It has also been argued that not all civil society organisations have identical effects in terms of political socialisation (Quintelier 2008). This argument can be extended to the geographical scale that members of organisations engage with: while we should expect membership in a development aid organisation to foster discussion mainly about the national (and international) realms of politics, a leisure association for the elderly probably does not exert a similar effect. We can expect that the effect exerted by organisations upon their members' level of engagement should be a function of their preferential scope of intervention. Thus, we expect that:

H4.A - A more intense involvement with civil society organisations oriented towards the national level will lead to more frequent discussion about national politics.

H4.B - A more intense involvement with civil society organisations oriented towards the local level will lead to more frequent discussion about local politics.

In addition to the individual-level factors outlined above, the study of the roots of political discussion has evolved by also looking at the impact of macro contexts, which have been found to play a key role in explaining cross-national differences. Indeed, Inglehart's $(1990,352)$ assertion that nationality is the "strongest predictor of political discussion" was followed by several attempts to understand whether such macro differences could be attributed to structural and cultural factors. Thus, Van Deth and Elff (2004) find that economic development fosters the levels of discussion about politics. These findings are in line with the results from research about the levels of political participation in Eastern Europe (M. Hooghe and Quintelier 2014).

We hypothesise that higher levels of economic development will tend to be associated with a higher interest in national, rather than local, politics. Modernisation theory suggests that economic development produces a homogeneously integrated, national public, increasingly void of the peculiarities of local political subcultures (Sellers et al. 2013). On the other hand, following Tarrow (1971), it can be hypothesised that individuals from comparatively lower income contexts can feel detached from the national level of politics, while keeping the habit of discussing the more proximate local political realm. Our fifth hypothesis thus reads:

H5 - Living in a country with a higher GDP will increase the likelihood to engage in discussions about national politics.

When it comes to the impact of institutional variables in political discussion, research has shown that more inclusive rules can pave the way to higher levels of 
political discussion (Kittilson and Schwindt-Bayer 2010; Nir 2012). Specifically, by exploiting the interaction of micro and macro level variables, these studies show how the gender gap in levels of political engagement can be reduced in the face of inclusive institutions.

Following these results, we posit that the level of decentralization of the system can also have an effect in making citizens engaged with the local level of politics. Specifically, we hypothesise that citizens will be more likely to develop an interest in what is going on at the local level if it bears significance for their lives. In their seminal study, Almond and Verba $(1965,125)$ stress that the patterns of citizens' attitudes towards their local governments vary precisely because the "structure of government and community organization changes from one nation to another". It has also been shown by Fitzgerald and Wolak (2014) that levels of trust in local and regional authorities vary as a function of the degree decentralization of a polity. Thus, our final hypothesis reads:

H6 - Living in a more decentralized country will be associated with a higher level of interest in local politics

\section{DATA AND METHODS}

Several studies about (generalist) political discussion in Europe (Inglehart 1990; Sanders and Bellucci 2012; van Deth and Elff 2004) rely on data from the Eurobarometer, which since 1973 has asked the following question: "When you get together with friends would you say you discuss political matters frequently, occasionally or never?" Our research question requires data about political discussion vis-à-vis multiple geographical scales, which this item does not provide. However, since 2010 the Eurobarometer surveys have often included a question that replicates the above formulation for local, national, and European matters.

Eurobarometer 73.4 (European Commission 2013, fieldwork: May 2010), was selected among possible alternatives since it featured questions that allowed testing our hypotheses. The survey was conducted in 31 European countries, namely all current member states of the European Union and the United Kingdom, plus Turkey, North Macedonia, and Iceland. We opted for keeping the complete set of countries as we want to test our hypotheses in as wide a set of polities as possible. By also including non-member-states, we expand the range of economic development and political trajectories of countries, which increases the potential for generalization of our findings.
Tab. 1. Profiles of engagement across territorial levels.

\begin{tabular}{lcccc}
\hline & & \multicolumn{3}{c}{ Local matters } \\
\cline { 3 - 5 } & & Never & Occasionally & Frequently \\
\hline \multirow{2}{*}{ National } & Never & $\mathrm{D}$ & $\mathrm{L}$ & $\mathrm{L}$ \\
matters & Occasionally & $\mathrm{N}$ & $\mathrm{E}$ & $\mathrm{L}$ \\
& Frequently & $\mathrm{N}$ & $\mathrm{N}$ & $\mathrm{E}$ \\
\hline
\end{tabular}

Note to table Tab. 1: D: "Disengaged"; E: "Equally engaged"; N: "More engaged in national"; L: "More engaged in local" Original question: "When you get together with friends or relatives, would you say you discuss frequently, occasionally or never about...?" ("National political matters"; "European political matters"; "Local political matters") Source: European Commission (2013, QA2).

Our dependent variable is the profile of political discussion of respondents. As we are interested in the interplay between the engagement towards local and national political matters, a new variable was generated based on the combination of the values of the variables about "local" and "national" political discussion ${ }^{3}$. We simplify the range of outcomes by aggregating the nine possible combinations into four profiles of engagement (Table 1). "Disengaged" ("D") respondents are those who never discuss neither local nor national political matters. If individuals report an identical frequency of discussion (for instance, by occasionally discussing local and national politics), they are labelled as "equally engaged" ("E"). Respondents can be "more engaged in national discussions" ("N") or, conversely, "more engaged in local discussions" ("L"), if they report participating in discussions about either of them more frequently. Our goal is to assess what makes individuals more likely to fall in each of the profiles, and particularly in these last two.

As the dependent variable is categorical and nonordered, a classical linear model is not appropriate. The responses are also clustered at the country level, with two of the hypotheses being formulated accordingly. We thus rely on a multilevel logistic model and perform a series of contrasts in order to account for the non-binary nature of the response variable (Gelman and Hill 2007, 124). Since the dependent variable has four possible outcomes, we set three binomial contrasts, using the most frequent category of engagement profile ("E: equally interested") as a baseline against which the likelihood of an alternative response is tested ${ }^{4}$. In this case, the alter-

\footnotetext{
${ }^{3}$ The cases of individuals refusing to answer or responding "Don't know" were not taken into account.

${ }^{4}$ This follows the practice suggested by Begg and Gray (1984) and Agresti $(2002,273)$. It should be kept in mind that the choice of the reference category for the response variable does not affect the estimated probabilities or the fitted values (Dobson and Barnett 2018, 183).
} 
native response consists of displaying a profile other than "E" ("D: Disengaged", "N: more into national politics", and "L: more into local politics"). Overall, this procedure is equivalent with performing a (multilevel) multinomial logistic regression (Begg and Gray 1984), but relies on less demanding computational routines.

Independent variables at the individual and country level used in the model are summarised in Table 2. Hypothesis 1 will be tested using responses to a question about the respondent's gender, while hypothesis 2 will be examined using a question about the type of community the respondent lives in: a rural area, a small/middle town or a big town. Our third hypothesis poses that individuals with higher levels of educational achievement and with a higher socioeconomic status shall engage more in discussions about national politics, whereas the reverse should hold for less-educated, lower status individuals. For the purpose of testing this we include variables about the age upon completion of education and self-placement in the socioeconomic ladder. Hypothesis 4 takes into account the organisational memberships of respondents in 12 types of organisations. These organisations were classified as either having a local, national or hybrid scope ${ }^{5}$.

Hypotheses 5 and 6 are tested using country-level data. The 2010 figures of Gross Domestic Product per capita based on purchase power parity were obtained from the International Monetary Fund (2014) and transformed into the logarithmic scale. H6, about the impact of decentralization, is evaluated using the ratio of expenditure by local authorities $v i s-\grave{a}$-vis expenditures by the central government. We use this as a proxy for the relevance of local governments in respondents' lives: individuals from countries where local authorities spend more should be expected to be more affected by local level politics and therefore more likely to engage in discussions about it.

In order to control other individual factors identified in the literature about we include age and occupation as individual-level variables. When it comes to age, a curvilinear (inverted-U) effect has been attributed in fostering (generalist) political engagement. We include a variable for occupation, which can have three responses: inactive, professional/managerial and manual worker. While we do not expect these two variables to play a significant role in nurturing engagement towards a specific territorial level at the expense of other, we include them in the equation in order to account for their eventual effects.

The survey features 30,215 responses, of which complete data for the variables used in the model is available

${ }^{5}$ Details about the operationalisation of this variable are available in the appendix.
Tab. 2. Summary of independent variables used in the analysis.

\begin{tabular}{|c|c|c|c|c|}
\hline \multicolumn{5}{|l|}{ Individual level } \\
\hline \multicolumn{5}{|l|}{ Categories } \\
\hline Gender & \multicolumn{4}{|c|}{$\begin{array}{l}\text { Female: } 53.9 \% \\
\text { Male: } 46.1 \%\end{array}$} \\
\hline Age group & \multicolumn{4}{|c|}{$\begin{array}{l}\text { 15-24: } 12.5 \% \\
25-34: 15.3 \% \\
35-44: 17.5 \% \\
45-54: 17.5 \% \\
55-64: 16.7 \% \\
>64: 20.5 \%\end{array}$} \\
\hline Occupation & \multicolumn{4}{|c|}{$\begin{array}{l}\text { Non-active: } 53.1 \% \\
\text { Manual worker: } 27.5 \% \\
\text { Professional/Managerial: } 19.4 \%\end{array}$} \\
\hline $\begin{array}{l}\text { Type of } \\
\text { community }\end{array}$ & \multicolumn{4}{|c|}{$\begin{array}{l}\text { Rural: } 36 \% \\
\text { Small/middle town: } 35.1 \% \\
\text { Big town } 28.9 \%\end{array}$} \\
\hline Continuous & Min & Max & Mean & Std. Dev \\
\hline $\begin{array}{l}\text { Organisational } \\
\text { membership } \\
\text { in national } \\
\text { organisations }\end{array}$ & $\begin{array}{c}0 \text { (not } \\
\text { members) }\end{array}$ & $\begin{array}{c}3(3+ \\
\text { organisations) }\end{array}$ & 0.32 & 0.69 \\
\hline $\begin{array}{l}\text { Organisational } \\
\text { membership } \\
\text { in local } \\
\text { organisations }\end{array}$ & $\begin{array}{c}0 \text { (not } \\
\text { member) }\end{array}$ & $\begin{array}{c}3(3+ \\
\text { organisations) }\end{array}$ & 0.38 & 0.71 \\
\hline $\begin{array}{l}\text { Age when } \\
\text { finished full-time } \\
\text { education }\end{array}$ & $\begin{array}{c}10 \text { (or } \\
\text { younger) }\end{array}$ & 26 (or older) & 18.5 & 3.8 \\
\hline $\begin{array}{l}\text { Socio-economic } \\
\text { status (self- } \\
\text { placement) }\end{array}$ & 1 & 10 & 5.4 & 1.7 \\
\hline Country level & Min & $\operatorname{Max}$ & Mean & Std. Dev \\
\hline $\begin{array}{l}\log (\text { GDP } \\
2010[\text { USD] })\end{array}$ & 8.44 & 11.56 & 10.02 & 0.72 \\
\hline $\begin{array}{l}\text { Local } \\
\text { government } \\
\text { spending } \\
\text { / central } \\
\text { government } \\
\text { spending }\end{array}$ & 0.014 & 0.644 & 0.283 & 0.14 \\
\hline
\end{tabular}

Note to Tab. 2: $\mathrm{n}=28,563$ individuals from 31 countries: France, Belgium, The Netherlands, Germany, Italy, Luxembourg, Denmark, Ireland, United Kingdom, Greece, Spain, Portugal, Finland, Sweden, Austria, Cyprus, Czech Republic, Estonia, Hungary, Latvia, Lithuania, Malta, Poland, Slovakia, Slovenia, Bulgaria, Romania, Turkey, Croatia, Macedonia, and Iceland. 
for 28,563 cases. The data analysis was carried out using $\mathrm{R}$ and the models were fitted using package lme4 (Bates et al. 2020).

\section{RESULTS}

Before examining the performance of our statistical models we glance at how frequently European citizens discuss both local and national political affairs. Figure 1 shows a remarkable similitude between the intensity of discussion about both realms of politics. This raises the possibility that the overwhelming majority of respondents state the same frequency of discussion for both national and local politics, which would challenge the relevance of testing the determinants of engagement separately.

We probe this by looking at the distribution of profiles of political engagement, computed as explained in the previous section. The distribution of this variable, pooled (Table 3) and within countries (Figure 2), shows that a robust degree of association exists between the regularity of discussion about both levels of politics, with around $73 \%$ of respondents reporting identical frequencies: approximately 55\% state that they occasionally or frequently discuss both levels, while $18 \%$ report never discussing neither of them. The reverse angle, however, is that more than a quarter of respondents report an unequal likelihood of entertaining discussions about the two geographical scales. The proportion of those in the sample reporting a higher interest in local politics (14.6\%) exceeds, even if by a small margin, those reporting a higher interest in national politics (12.6\%). This balance between the two profiles is a noteworthy find-

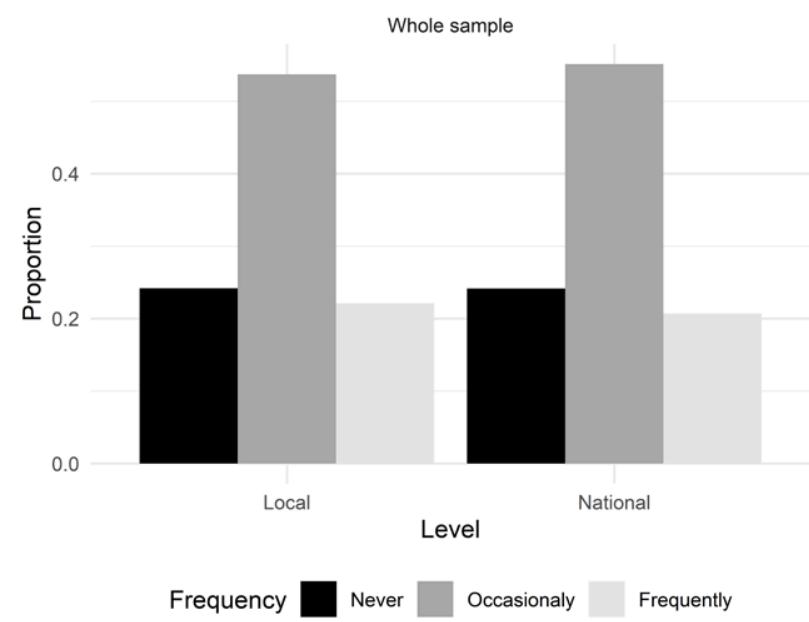

Fig. 1. Frequency of political discussion by geographical scale. ing on itself, as it signals that engagement with national political matters does not exceed involvement in local affairs.

Similarly to van Deth and Elff (2004), and Sanders and Bellucci (2012) we also find considerable levels of variation in political discussion across countries (Figure 2). Disengaged citizens are typically more abundant in Southern and Eastern Europe and scarcer in Northwestern Europe - Greece being an exception as noted in prior research (van Deth and Elff 2004). In most countries the broader pattern of having similar proportions of citizens who are more interested in local matters, on the one hand, and national politics, on the other, is replicated. It is also noteworthy that the proportion of individuals who are more engaged with national politics shows higher variance across countries than the proportion of individuals who are more engaged with local politics. As will be seen, this has direct implications for our sixth hypothesis. Still, the ratio is not constant: in some countries interest in local politics is more widespread (e.g. Croatia, Bulgaria or Italy), while in others (e.g. Iceland, the Netherlands) the opposite happens.

We now focus on the results of our statistical analysis. Table 4 reports the odds ratios for the three contrasts, along with lower and upper bounds of their 95\% confidence intervals. Each column from (1) to (3) reproduces results relative to a contrast between the baseline ("equally engaged") and one of the alternative outcomes. The odds ratios express the effect that a one unit change in one of the independent variables brings to the likelihood of moving from the baseline outcome "equally engaged" ("E") towards one of the alternative outcomes: "disengaged" ("D"), “more engaged in national matters" ("N"), and "more engaged in local matters" ("L"). For instance, the odds ratio associated with the category "female" in the first column is 1.59. In this case, the 95\% confidence interval does not contain 1 (no effect), which indicates that the underlying logit coefficient is statistically significant. Thus, we can be relatively confident that female respondents are

Tab. 3. Frequency of outcomes: profiles of engagement.

\begin{tabular}{|c|c|c|}
\hline Profile & Frequency & Percent in sample \\
\hline $\begin{array}{l}\text { Disengaged - Not interested in } \\
\text { none (D) }\end{array}$ & 5,014 & 17.6 \\
\hline Equally interested (E) & 15,797 & 55.3 \\
\hline More into national $(\mathrm{N})$ & 3,591 & 12.6 \\
\hline More into local (L) & 4,161 & 14.6 \\
\hline Total & 28,563 & 100 \\
\hline
\end{tabular}




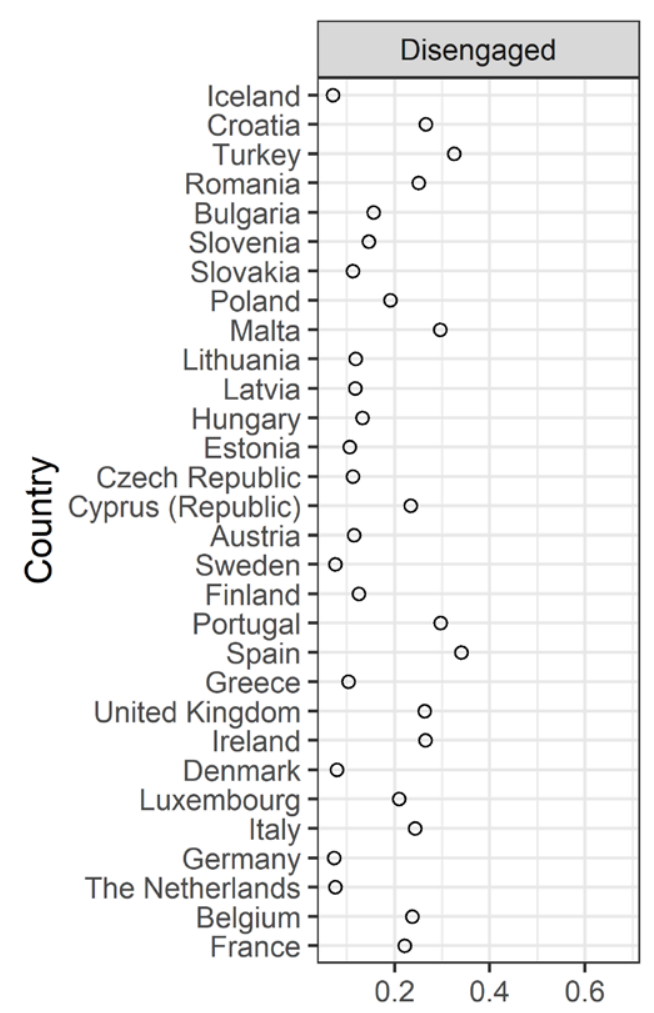

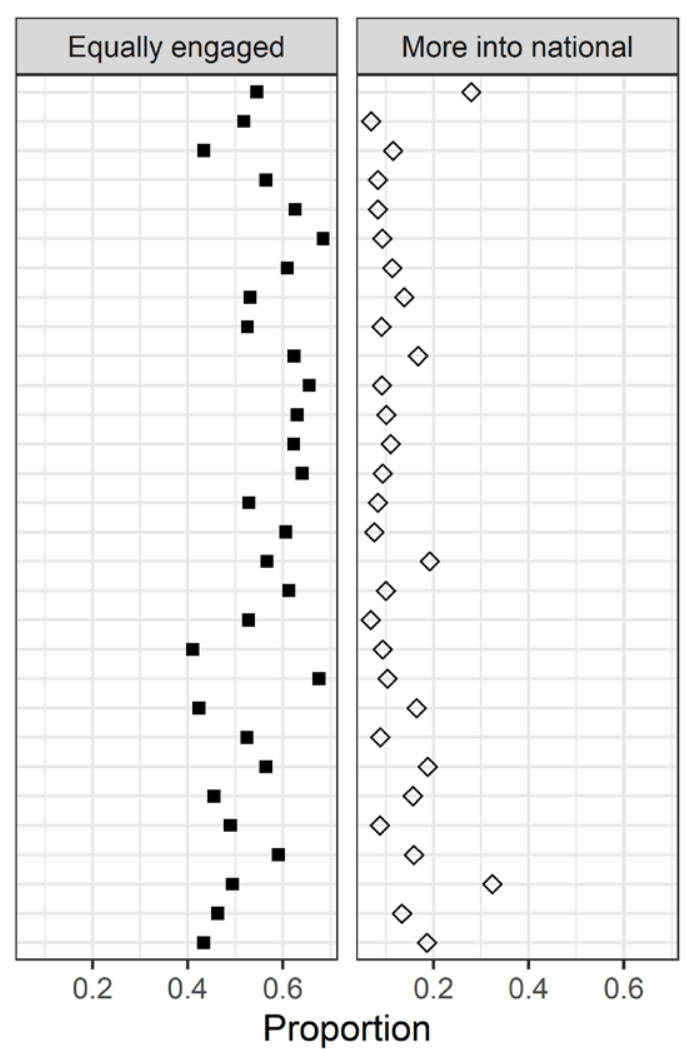

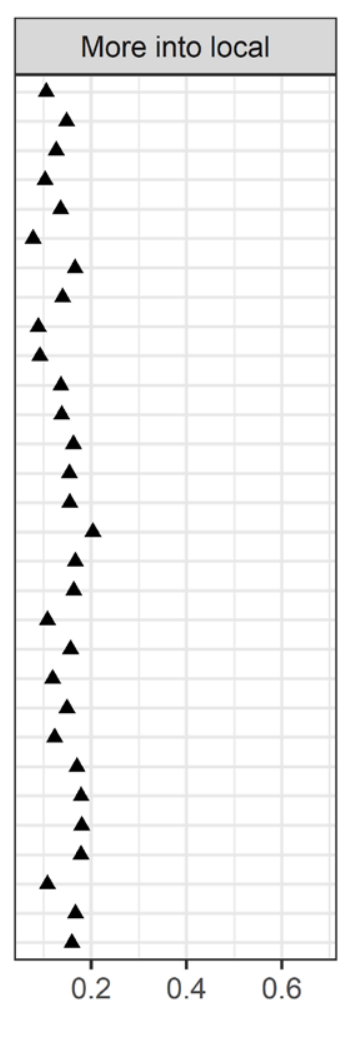

\section{Profile $\circ$ Disengaged - Equally engaged $\diamond$ More into national $\Delta$ More into local}

Fig. 2. Distribution of profiles of engagement within countries (proportions).

about 1.59 times as likely to fall in profile " $D$ ” when compared to male respondents ${ }^{6}$.

Before proceeding to the results in the second and third columns, which are those of greater interest given our research question, we glance at the odd ratios reproduced in column (1), assessing the impact of the tested variables in the probability of being disengaged towards both levels of politics. Overall, the findings are in line with previous research about the roots of generalist political discussion. Higher socioeconomic status and more years of education, as well as being male, increase the likelihood of being equally engaged in both levels of politics rather than disengaged. The effect of age resembles a skewed and inverted U-shape, with the age group more likely to be involved in politics being the 55-64 years segment. Being a member of multiple civil society organisations focused on the local level of politics also increases the likelihood of engaging in political discus-

\footnotetext{
${ }^{6}$ In order to provide a fuller portrait of the results, the appendix reports the underlying logit coefficients of the three models.
}

sion as opposed to staying disengaged. Interestingly, the odds ratios of the two macro-level covariates are near 1 and deprived of significance.

The most interesting results given our research question are those reproduced in columns (2) and (3), which present the odds ratios for the contrasts between the common baseline "E" and the alternative outcomes "N" and "L". When compared to the results of contrast (1), the odds ratios are closer to 1, suggesting that the explanatory variables are less powerful as predictors of moving from the baseline to the other outcomes.

In order to improve the interpretability of the results, the plots reproduced in Figure 3 illustrate the effect of changes in the independent variables of interest. Figure 3 focuses on just two of the alternatives to the baseline, " $N$ " and "L", leaving aside the predicted probabilities of being disengaged towards both levels of politics. Each plot within the figure shows the predicted probability of moving from the baseline " $E$ " towards one of the outcomes " $N$ " and "L", given the values for the independent variables expressed in the horizon- 
Tab. 4. Multilevel logit model odds ratios.

\begin{tabular}{|c|c|c|c|}
\hline & \multicolumn{3}{|c|}{$\begin{array}{c}\text { Dependent variable: Profile of political engagement } \\
\text { Baseline: Equally engaged in local and national discussions } \\
\text { Contrast }\end{array}$} \\
\hline & $\begin{array}{l}\text { Disengaged } \\
\text { (1) }\end{array}$ & $\begin{array}{l}\text { More into national } \\
\text { (2) }\end{array}$ & $\begin{array}{l}\text { More into local } \\
\text { (3) }\end{array}$ \\
\hline \multicolumn{4}{|c|}{ Fixed effects } \\
\hline Intercept & $2.34(-0.16,4.83)$ & $0.01(-1.85,1.87)^{*}$ & $0.23(-1.16,1.62)^{+}$ \\
\hline \multicolumn{4}{|c|}{ Individual level } \\
\hline Female & $1.59(1.52,1.66)^{*}$ & $0.87(0.79,0.94)^{*}$ & $1.20(1.13,1.27)^{*}$ \\
\hline \multicolumn{4}{|c|}{ Age group (ref: 15-24) } \\
\hline 25-34 years & $0.63(0.51,0.76)^{*}$ & $0.69(0.55,0.84)^{*}$ & $0.78(0.64,0.92)^{*}$ \\
\hline $35-44$ years & $0.45(0.33,0.58)^{*}$ & $0.66(0.51,0.80)^{*}$ & $0.73(0.59,0.87)^{*}$ \\
\hline $45-54$ years & $0.38(0.25,0.51)^{*}$ & $0.64(0.50,0.79)^{*}$ & $0.69(0.56,0.83)^{*}$ \\
\hline 55-64 years & $0.31(0.18,0.43)^{*}$ & $0.57(0.43,0.71)^{*}$ & $0.67(0.53,0.80)^{*}$ \\
\hline$>64$ years & $0.41(0.30,0.53)^{*}$ & $0.61(0.48,0.75)^{*}$ & $0.80(0.67,0.93)^{*}$ \\
\hline \multicolumn{4}{|c|}{ Occupation (ref: inactive) } \\
\hline Professional/Managerial & $0.66(0.56,0.77)^{*}$ & $0.94(0.84,1.04)$ & $0.89(0.79,0.99)^{+}$ \\
\hline Manual worker & $0.93(0.83,1.03)$ & $1.02(0.91,1.13)$ & $1.11(1.00,1.21)$ \\
\hline Education & $0.89(0.88,0.91)^{*}$ & $1.03(1.02,1.04)^{*}$ & $0.97(0.96,0.98)^{*}$ \\
\hline Socioeconomic status & $0.92(0.90,0.94)^{*}$ & $1.00(0.98,1.02)$ & $0.95(0.92,0.97)^{*}$ \\
\hline National CSO & $0.96(0.88,1.05)$ & $1.08(1.01,1.16)^{+}$ & $0.95(0.87,1.02)$ \\
\hline Local CSO & $0.73(0.64,0.81)^{*}$ & $0.90(0.83,0.98)^{\ddagger}$ & $1.13(1.06,1.20)^{*}$ \\
\hline \multicolumn{4}{|c|}{ Community (base: Rural) } \\
\hline Small/Middle town & $0.98(0.90,1.06)$ & $1.09(1.00,1.18)$ & $0.90(0.82,0.98)^{+}$ \\
\hline Big town & $0.98(0.90,1.07)$ & $1.14(1.05,1.23)^{\ddagger}$ & $0.68(0.59,0.77)^{*}$ \\
\hline \multicolumn{4}{|c|}{ Country level } \\
\hline$\overline{\log (G D P / c a p i t a)}$ & $1.13(0.87,1.39)$ & $1.30(1.11,1.49)^{\ddagger}$ & $1.13(0.99,1.27)$ \\
\hline Local expenditures & $0.55(-0.75,1.85)$ & $1.73(0.76,2.70)$ & $1.88(1.17,2.60)$ \\
\hline \multicolumn{4}{|c|}{ Random effects } \\
\hline Standard deviation of intercept & 1.27 & 0.35 & 0.25 \\
\hline $\mathrm{N}$ (individuals) & 21,303 & 19,744 & 20,299 \\
\hline Log likelihood & $-10,444.88$ & $-9,167.05$ & $-10,160.79$ \\
\hline Akaike information criterion & $20,925.76$ & $18,370.10$ & $20,357.58$ \\
\hline
\end{tabular}

Note to Tab. 4: Each cell presents the odds ratio (with lower and upper limit of a $95 \%$ confidence interval in brackets) effect of a one-unit change in the value of each independent variable in moving from the baseline outcome $\mathrm{E}$ ("equally engaged") towards each alternative outcome within the three contrasts: D ("disengaged at both levels of politics"), N ("discusses more national politics"), L ("discusses more local politics").

P value: ${ }^{+}<0.05 ;{ }^{\ddagger}<0.01 ;{ }^{*}<0.001$. 

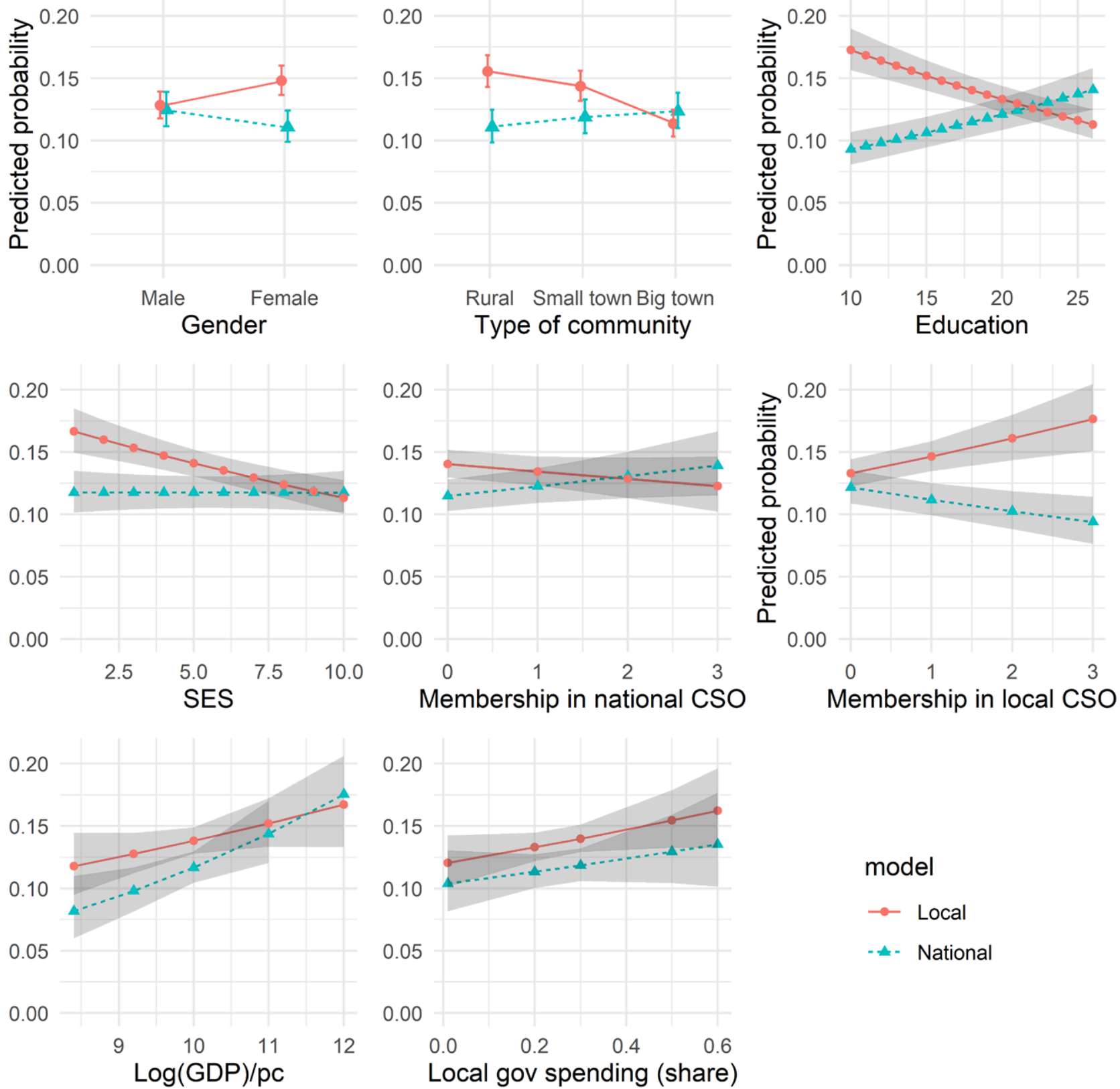

Fig. 3. Predicted probabilities of alternative outcomes by selected values. Note: Each probability value as extracted from the logit model was multiplied by the proportion of respondents in each contrast over the total number of respondents analysed. This procedure ensures that the sum of the predicted probabilities of the four alternative outcomes adds up to 1 .

tal axis, while holding the remaining variables at their mean value. In order to present a sensible probability estimate we must take into account that the sum of probabilities for the four possible outcomes must add up to 1 . Thus, each estimated value is multiplied by the proportion of individuals in each contrast relative to the overall sample.
Each line (in the case of continuous variables) and point (in the case of categorical variables) is supplemented by a $95 \%$ confidence interval. A positive slope indicates a positive relationship between an increase in the value of the independent variable value and the probability of moving from the baseline response ("E") towards the alternative outcome ("N", or "L"). Since in 
all of the three contrasts the binomial distribution is skewed towards " $E$ ", the range of predicted probabilities is relatively narrow. However, the proportions of "E" are roughly equivalent across the two contrasts, which contributes to ease the comparability between coefficients and predicted probabilities.

The first hypothesis posited the existence of a significant difference between the likelihood of men and women fitting into the different profiles of our typology. The hypothesis is corroborated: as the odd ratios in table 3 and the top-left plot in figure 2 suggest, women are about 4 percentage points more likely to fall into profile "L" than they are to fall into profile "N". This means that the original finding of Coffé (2013) is replicated on a wider set of countries: women are not necessarily more detached from politics than men, but they are instead often more involved with other types of matters.

Our second hypothesis argued that inhabitants in different types of communities would show different degrees of engagement towards different territorial levels. The plotted probabilities in Figure 3 show that living in a rural area is a useful predictor of the type of discussions individuals engage with. In the contrast between the baseline category and the alternative outcome of being more engaged in discussions about local politics, inhabitants from rural areas have a predicted probability of being more engaged in local politics of 0.16 , as opposed to 0.11 of residents in big towns. The difference is statistically significant at the $95 \%$ confidence level. The results also show that living in a rural area does not foster discussion about national politics in a comparable way: the predicted probability of moving from the baseline towards the alternative outcome " $\mathrm{N}$ " is 0.12 , which does not significantly differ from the 0.11 of residents of cities. The effect of the type of community is not symmetrical in the sense that there is not a comparable gap between the inclination to talking about national politics between residents in big cities and residents in rural areas.

According to our third hypothesis, individuals with higher levels of education and socioeconomic status should be more prone to discussing national politics than respondents who are less educated and have a lower status. The results show that, on average, each year of completed education gives respondents a 0.3 percentage point higher probability of moving towards " $\mathrm{N}$ " and a 0.5 percentage point lower probability of moving towards " $\mathrm{L}$ ". The implication is that our hypothesis is confirmed especially outside the central values of the distribution: individuals who left school before turning 18 years old (who correspond to approximately $40 \%$ of the sample) are more likely to be engaged in local poli- tics; conversely, those who finished their education by the age of 24 or older ( $10 \%$ of respondents in the sample) are more likely to report a higher engagement towards national politics. The impact of self-reported SES is more modest, as shown by the less steep slopes. While respondents who identify as a having a status of 3 or lower (13\% of the sample) are more likely to fall in the " $L$ " category, the differences fall outside statistical significance for the remaining cases.

Hypothesis 4 regards organisational membership and has a twofold formulation. H4.A posited that membership in organisations oriented towards the national level would have an effect in fostering discussion about national politics. However, this is not corroborated by our analysis. A respondent who is not a member of any organisation with a national scope has a 0.11 probability of being more engaged in discussions about national politics, and an increase of one (organisation) brings only a 0.01 increase in the chance of moving from the baseline towards profile "N".

H4.B, on the other hand, argued that members of organisations with a local scope will be more likely to engage in discussions about local affairs. Thus, the effect of membership in local associations seems to be stronger: each membership brings a 0.02 change of moving from the baseline towards " $\mathrm{L}$ " and a -0.02 change in moving towards "N". In practical terms, a member of one single association devoted to local issues (17.9\% of the sample) has a 0.12 chance of being more engaged in national discussions, and a 0.15 of being more engaged in local politics. As the ribbons in the plot do not intersect, this difference is statistically significant. The effect is amplified if the respondent is a member of two or three or more such organisations, but the number of respondents under these circumstances is low $(5.7 \%$ and $2.6 \%$ respectively).

Our second set of hypotheses deals with macro-level factors. Figure 2 shows that variations within countries regarding the distribution of the "N" and "L" profiles are not very salient. However, we cannot reject the possibility of macro-level factors mitigating or exacerbating the effect of individual-level variables; therefore, testing hypotheses formulated at the country-level remains a crucial part of the analysis.

Hypothesis 5 posited that living in a wealthier country would enhance the probability of being more engaged in national politics. The plot shows that moving from the lower end of the spectrum of logged GDP values towards its upper end doubles the predicted probability of having a profile of type " $\mathrm{N}$ " from 0.08 to 0.16 . However, as the ribbon around the line illustrates, there is a large error associated with this estimate, and 
the predicted probabilities for intermediate positions of GDP per capita are so close to each other that their differences are not statistically significant. Also, contrary to our hypothesis, a higher GDP also seems to foster the likelihood of moving from the baseline towards a higher interest in local matters, although the slope is smaller and the associated error is higher. Therefore, while there seems to be evidence of an impact of economic development in increasing the likelihood of discussing national politics, the effect is not as strong or exclusive to national politics as initially expected.

Finally, the hypothesis that living in a more decentralized country stimulates the propensity to discuss local matters (H6) is not fully met. While it is true that individuals from countries where local governments are responsible for a negligible fraction of public expenditure will tend to discuss local politics less often than individuals from countries where the local government spends more, the errors associated with those predictions are large. Moreover, an increase in the proportion of money spent also leads to a small growth in the probability of discussing national politics. Taken together, the results of the two macro-level hypotheses suggest that country-level factors may not play a relevant role in inducing individuals to move to specifically inducing discussion about either local or national issues.

\section{CONCLUSIONS}

While it would be an overstatement to argue that geographical scales have been completely absent from the research about comparative political behaviour, there is a scarcity of cross-national studies about the drivers of involvement towards different levels of politics. This article made use of survey data collected in a wide set of European polities to show that the frequency of political discussion about different territorial levels is not a function of the same set of factors. Gender, education, the types of organisation one is a member of or the type of community one lives in, for instance, play a significant role in determining the type of political discussions one is more likely to engage with.

Conversely, evidence of the impact of macro-level factors in fostering a differential engagement towards distinct territorial levels is not as compelling as initially hypothesised, despite earlier research having established that contextual factors matter a good deal to the intensity of generalist political engagement (Inglehart 1990). Even in countries in an advanced stage of economic development, there is the persistence of groups of individuals who remain more likely to discuss local affairs.
Furthermore, high levels of engagement with local politics do not seem to be an exclusive attribute of those living in highly decentralised countries. Given these results, it can be fruitful for future studies to add the temporal dimension into the analysis, by examining surveys conducted over multiple periods of time and testing whether the evolution of macro-contexts brings changes to the probability of being more engaged in discussing one specific level of politics.

Two further implications can be derived from our results, the first being of a substantive nature. A classical thesis about political change in developed countries asserts that a process of "nationalization of politics" dilutes local peculiarities and, consequently, their role as fosterers of political engagement (Caramani 2004; Sellers et al. 2013, 1-10). Our analysis shows that the profile of an engaged citizen is not as rigidly defined as could be assumed if we focused exclusively on the national level of politics. Across Europe, an important share of individuals in groups that are perceived apathetic towards politics writ large regularly take part in discussions about local political affairs. Thus, in a context of growing disengagement towards politics (Dēmētriou 2013, 6-7), the findings of this article suggest that interest in local affairs still plays a role in keeping a sizable share of individuals attached to the political realm, even if outside the scope of national politics. This potential effect of local engagement in bringing more citizens into a broader domain politics should not be overlooked by scholars and policymakers.

The second implication is methodological and is related to the underlying assumptions that members of the public may hold when answering questions about their political engagement. Indeed, the bias towards identifying politics exclusively with the national level of politics may not be restricted to authors. Our results signal that determinants of discussion about national politics, more than those for discussion of local matters, are in line with the explanatory variables of generalist political discussion (van Deth and Elff 2004; Sanders and Bellucci 2012). As Fizgerald (2013) demonstrates, a diversity of parallel conceptions of what is and is not political might coexist across the public; nevertheless, the performance of our model suggests that generalist studies may capture an underlying conception of "politics" that identifies it essentially with the national scale. In order to avoid crystallising an identification of politics with only one of its territorial axes, more research should keep into account investment in those different spheres. While this approach has already been followed in studies about voter turnout and party choice in local elections (Lefevere and Van Aelst 2014; Marien, Dassonneville, and Hooghe 
2015), it should be extended to other dimensions of political behaviour. One direction that might prove particularly fruitful in the future is analysing whether individuals who exhibit different profiles are involved in different modes of political participation.

It should be clear that we do not advocate that focusing only on the national level of politics or that embracing a generalist perspective are malpractices in the study of political engagement. Indeed, either approach may be the most fruitful in light of researchers' particular goals. However, by invariably following either of these strategies we may end up ignoring important shades of how citizens practice their democratic citizenship.

\section{REFERENCES}

Agnew, John. 2002. Place and Politics in Modern Italy. Chicago: University of Chicago Press.

Agresti, Alan. 2002. Categorical Data Analysis. Hoboken: John Wiley \& Sons.

Almond, Gabriel, and Sidney Verba. 1965. The Civic Culture; Political Attitudes and Democracy in Five Nations. Boston: Little, Brown.

Bates, Douglas, Martin Maechler, Ben Bolker [aut, cre, Steven Walker, Rune Haubo Bojesen Christensen, Henrik Singmann, et al. 2020. Lme4: Linear MixedEffects Models Using 'Eigen' and S4 (version 1.1-23). https://CRAN.R-project.org/package=lme4.

Baybeck, Brady. 2014. 'Local Political Participation'. In The Oxford Handbook of State and Local Government, edited by Donald P. Haider-Markel, 95-109. Oxford: Oxford University Press. http://oxfordindex.oup.com/ view/10.1093/oxfordhb/9780199579679.013.009.

Begg, Colin B., and Robert Gray. 1984. 'Calculation of Polychotomous Logistic Regression Parameters Using Individualized Regressions. Biometrika 71 (1): 11-18. https://doi.org/10.1093/biomet/71.1.11.

Cancela, João, and Benny Geys. 2016. 'Explaining Voter Turnout: A Meta-Analysis of National and Subnational Elections'. Electoral Studies 42 (June): 264-75. https://doi.org/10.1016/j.electstud.2016.03.005.

Caramani, Daniele. 2004. The Nationalization of Politics. Cambridge: Cambridge University Press.

Coffé, Hilde. 2013. 'Women Stay Local, Men Go National and Global? Gender Differences in Political Interest'. Sex Roles 69 (5-6): 323-38. https://doi.org/10.1007/ s11199-013-0308-x.

Dalton, Russell. 2014. Citizen Politics: Public Opinion and Political Parties in Advanced Industrial Democracies.

Dēmētriou, Kyriakos N. 2013. 'Introduction'. In Democracy in Transition: Political Participation in the Euro- pean Union. Heidelberg; New York: Springer-Verlag. http://public.eblib.com/choice/publicfullrecord. aspx? $\mathrm{p}=1082483$.

Deth, Jan van. 2014. 'A Conceptual Map of Political Participation'. Acta Politica 49 (3): 349-67. https://doi. org/10.1057/ap.2014.6.

Deth, Jan van, and Martin Elff. 2004. 'Politicisation, Economic Development and Political Interest in Europe'. European Journal of Political Research 43 (3): 477-508. https://doi.org/10.1111/j.14756765.2004.00162.x.

Dobson, Annette J, and Adrian G Barnett. 2018. An Introduction to Generalized Linear Models. Boca Raton: CRC Press / Chapman \& Hall.

European Commission. 2013. 'Eurobarometer 73.4: Financial and Economic Crisis, the Future of the European Union, Globalization, and European Citizenship, May 2010: Version 1'. https://dbk. gesis.org/dbksearch/sdesc2.asp?no $=5234 \& \mathrm{db}=\mathrm{e} \& \mathrm{~d}$ $\mathrm{oi}=10.4232 / 1.11479$.

Eveland, William P, and Myiah Hutchens Hively. 2009. 'Political Discussion Frequency, Network Size, and "Heterogeneity" of Discussion as Predictors of Political Knowledge and Participation. Journal of Communication 59 (2): 205-24. https://doi.org/10.1111/ j.1460-2466.2009.01412.x.

Fitzgerald, Jennifer. 2013. 'What Does Political Mean to You?' Political Behavior 35 (3): 453-79. https://doi. org/10.1007/s11109-012-9212-2.

Fitzgerald, Jennifer, and Jennifer Wolak. 2014. 'The Roots of Trust in Local Government in Western Europe'. International Political Science Review, August, advance online publication 25 August, doi: 10.1177/0192512114545119. https://doi. org/10.1177/0192512114545119.

Gelman, Andrew, and Jennifer Hill. 2007. Data Analysis Using Regression and Multilevel/Hierarchical Models. Cambridge: Cambridge University Press.

Hooghe, Liesbet, and Gary Marks. 2001. Multi-Level Governance and European Integration. Oxford: Rowman \& Littlefield.

Hooghe, Marc, and Ellen Quintelier. 2014. 'Political Participation in European Countries: The Effect of Authoritarian Rule, Corruption, Lack of Good Governance and Economic Downturn'. Comparative European Politics 12 (2): 209-32. https://doi. org/10.1057/cep.2013.3.

Inglehart, Ronald. 1990. Culture Shift in Advanced Industrial Society. Princeton, NJ: Princeton University Press.

International Monetary Fund. 2014. 'World Economic Outlook Database'. Http://www.imf.org/external/ 
pubs/ft/weo/2014/02/weodata/index.aspx , accessed 2 March 2015. 2014.

Kittilson, Miki Caul, and Leslie Schwindt-Bayer. 2010. 'Engaging Citizens: The Role of Power-Sharing Institutions'. Journal of Politics 72 (4): 990-1002. https:// doi.org/10.1017/S0022381610000484.

Lee, Francies L.F. 2009. 'The Impact of Political Discussion in a Democratizing Society: The Moderating Role of Disagreement and Support for Democracy'. Communication Research 36 (3): 379-99. https://doi. org/10.1177/0093650209333027.

Lefevere, Jonas, and Peter Van Aelst. 2014. 'First-Order, Second-Order or Third-Rate? A Comparison of Turnout in European, Local and National Elections in the Netherlands. Electoral Studies 35 (September): 159-70. https://doi.org/10.1016/j.electstud.2014.06.005.

Lijphart, Arend. 1997. 'Unequal Participation: Democracy's Unresolved Dilemma'. The American Political Science Review 91 (1): 1-14. https://doi. org/10.2307/2952255.

Mair, Peter. 2013. Ruling the Void the Hollowing of Western Democracy. London; New York: Verso.

Marien, Sofie, Ruth Dassonneville, and Marc Hooghe. 2015. 'How Second Order Are Local Elections? Voting Motives and Party Preferences in Belgian Municipal Elections'. Local Government Studies 41 (6): 898916. https://doi.org/10.1080/03003930.2015.1048230.

Meer, Tom van der, and Erik van Ingen. 2009. 'Schools of Democracy? Disentangling the Relationship between Civic Participation and Political Action in 17 European Countries. European Journal of Political Research 48 (2): 281-308. https://doi.org/10.1111/j.14756765.2008.00836.x.

Nir, Lilach. 2012. 'Cross-National Differences in Political Discussion: Can Political Systems Narrow Deliberation Gaps?' Journal of Communication 62 (3): 553-70. https://doi.org/10.1111/j.1460-2466.2012.01648.x.

Oliver, J. Eric. 2012. Local Elections and the Politics of Small-Scale Democracy. Princeton: Princeton University Press.

Putnam, Robert. 2000. Bowling Alone: The Collapse and Revival of American Community. New York: Simon \& Schuster.

Quintelier, Ellen. 2008. 'Who Is Politically Active: The Athlete, the Scout Member or the Environmental Activist?' Acta Sociologica 51 (4): 355-70. https://doi. org/10.1177/0001699308097378.

Rapeli, Lauri. 2014. 'Comparing Local, National and EU Knowledge: The Ignorant Public Reassessed'. Scandinavian Political Studies 37 (4): 428-46. https://doi. org/10.1111/1467-9477.12032.
Sanders, David, and Paolo Bellucci. 2012. 'Informal Political Engagement in Europe, 1975-2007'. In Citizens and the European Polity, edited by David Sanders, Pedro Magalhães, and Gabor Toka, 39-64. Oxford: Oxford University Press.

Sellers, Jefferey M, Daniel Kübler, Melanie Walter-Rogg, and Robert Alan Walks. 2013. The Political Ecology of the Metropolis: Metropolitan Sources of Electoral Behaviour in Eleven Countries. Colchester: ECPR Press.

Shaker, Lee. 2012. 'Local Political Knowledge and Assessments of Citizen Competence'. Public Opinion Quarterly 76 (3): 525-37. https://doi.org/10.1093/poq/ nfs018.

Tarrow, Sidney. 1971. 'The Urban-Rural Cleavage in Political Involvement: The Case of France. The American Political Science Review 65 (2): 341-57. https://doi. org/10.2307/1954453.

Verba, Sidney, Kay Lehman Schlozman, and Henry E Brady. 1995. Voice and Equality: Civic Voluntarism in American Politics. Cambridge: Harvard University Press. 


\section{APPENDIX}

\section{A.1. Classification of civil society organisations}

Respondents were asked whether they participated in 14 different types of organisations. These 14 types of organisations were classified depending on whether their scope of intervention was more local, national or, in ambiguous cases, both national and local.

The question asked to respondents was the following:

QE11: "Do you currently participate actively in or do voluntary work for one or more of the following organisations?"

Tab. A1. Classification of organisations.

\begin{tabular}{|c|c|c|c|c|}
\hline Var & Option & Description of organization & $\begin{array}{c}\text { Percent in } \\
\text { sample }\end{array}$ & Scope \\
\hline v514 & 1 & A sports club or club for outdoor activities (recreation organisation) & $10 \%$ & Local \\
\hline v515 & 2 & Education, arts, music or cultural association & $7 \%$ & Both \\
\hline v516 & 3 & A trade union & $4 \%$ & National \\
\hline v517 & 4 & A business or professional organisation & $3 \%$ & National \\
\hline v518 & 5 & A consumer organisation & $2 \%$ & National \\
\hline v519 & 6 & $\begin{array}{c}\text { An international organisation such as development aid organisation or human rights } \\
\text { organisation }\end{array}$ & $2 \%$ & National \\
\hline v520 & 7 & An organisation for environmental protection, animal rights, etc. & $3 \%$ & National \\
\hline v521 & 8 & A charity organisation or social aid organisation & $5 \%$ & Local \\
\hline v522 & 9 & A leisure association for the elderly & $3 \%$ & Local \\
\hline v523 & 10 & An organisation for the defence of elderly rights & $1 \%$ & Both \\
\hline v524 & 11 & Religious or church organization & $5 \%$ & Both \\
\hline v525 & 12 & Political party or organisation & $2 \%$ & Both \\
\hline v526 & 13 & Organisation defending the interest of patients and $\backslash$ or disabled & $2 \%$ & Both \\
\hline v527 & 14 & $\begin{array}{c}\text { Other interest groups for specific causes such as women, people with specific sexual } \\
\text { orientation, local issues, etc. }\end{array}$ & $10 \%$ & Both \\
\hline
\end{tabular}


Tab. A2. Multilevel logit model coefficients.

\begin{tabular}{|c|c|c|c|}
\hline & \multicolumn{3}{|c|}{$\begin{array}{c}\text { Dependent variable: Profile of political engagement } \\
\text { Baseline: Equally engaged in local and national discussions } \\
\text { Contrast }\end{array}$} \\
\hline & $\begin{array}{c}\text { Disengaged } \\
(1)\end{array}$ & $\begin{array}{l}\text { More into national } \\
\text { (2) }\end{array}$ & $\begin{array}{c}\text { More into local } \\
\text { (3) }\end{array}$ \\
\hline \multicolumn{4}{|c|}{ Fixed effects } \\
\hline Intercept & $0.85(1.27)$ & $-4.45^{\star}(0.95)$ & $-1.54+(0.70)$ \\
\hline \multicolumn{4}{|c|}{ Individual level } \\
\hline Female & $0.46^{\star}(0.04)$ & $-0.14^{\star}(0.04)$ & $0.18^{\star}(0.04)$ \\
\hline \multicolumn{4}{|c|}{ Age group (ref: 15-24) } \\
\hline 25-34 years & $-0.46^{\star}(0.06)$ & $-0.37^{\star}(0.07)$ & $-0.25^{\star}(0.07)$ \\
\hline $35-44$ years & $-0.79^{\star}(0.06)$ & $-0.42^{\star}(0.07)$ & $-0.31^{\star}(0.07)$ \\
\hline $45-54$ years & $-0.97^{\star}(0.07)$ & $-0.44^{\star}(0.07)$ & $-0.36^{\star}(0.07)$ \\
\hline 55-64 years & $-1.18^{\star}(0.06)$ & $-0.56^{\star}(0.07)$ & $-0.41^{\star}(0.07)$ \\
\hline$>64$ years & $-0.89^{*}(0.06)$ & $-0.49^{\star}(0.07)$ & $-0.22^{\star}(0.07)$ \\
\hline \multicolumn{4}{|c|}{ Occupation (ref: inactive) } \\
\hline Professional/Managerial & $-0.41^{\star}(0.05)$ & $-0.06(0.05)$ & $-0.12+(0.05)$ \\
\hline Manual worker & $-0.07(0.05)$ & $0.02(0.06)$ & $0.10(0.05)$ \\
\hline Education & $-0.11^{\star}(0.01)$ & $0.03^{\star}(0.01)$ & $-0.03^{\star}(0.01)$ \\
\hline Socioeconomic status & $-0.08^{\star}(0.01)$ & $-0.0000(0.01)$ & $-0.05^{\star}(0.01)$ \\
\hline National CSO & $-0.04(0.04)$ & $0.08+(0.04)$ & $-0.06(0.04)$ \\
\hline Local CSO & $-0.32^{*}(0.04)$ & $-0.10 \ddagger(0.04)$ & $0.12^{\star}(0.04)$ \\
\hline \multicolumn{4}{|c|}{ Community (base: Rural) } \\
\hline Small/Middle town & $-0.02(0.04)$ & $0.08(0.05)$ & $-0.10+(0.04)$ \\
\hline Big town & $-0.02(0.04)$ & $0.13 \ddagger(0.05)$ & $-0.39^{*}(0.05)$ \\
\hline \multicolumn{4}{|c|}{ Country level } \\
\hline $\log (\mathrm{GDP} /$ capita $)$ & $0.12(0.13)$ & $0.26 \ddagger(0.10)$ & $0.12(0.07)$ \\
\hline Local expenditures & $-0.60(0.66)$ & $0.55(0.49)$ & $0.63(0.36)$ \\
\hline \multicolumn{4}{|c|}{ Random effects } \\
\hline Standard deviation of intercept & 1.27 & 0.35 & 0.25 \\
\hline $\mathrm{N}$ (individuals) & 21,303 & 19,744 & 20,299 \\
\hline Log likelihood & $-10,444.88$ & $-9,167.05$ & $-10,160.79$ \\
\hline Akaike information criterion & $20,925.76$ & $18,370.10$ & $20,357.58$ \\
\hline
\end{tabular}

Note to Tab. A2: Each cell presents the logit coefficient (with standard error in brackets) associated with a one-unit change in the value of each independent variable in moving from the baseline outcome E ("equally engaged") towards each alternative outcome within the three contrasts: D (“disengaged at both levels of politics"), $\mathrm{N}$ (“discusses more national politics"), L (“discusses more local politics").

P value: ${ }^{+}<0.05 ;{ }^{\ddagger}<0.01 ;{ }^{*}<0.001$. 